\title{
KEPERIBADIAN ISLAM DAN PROFESIONALISME DALAM PEKERJAAN: SATU ANALISIS TEORITIS
}

\section{Islamic Personality and Professionalism at Work: A Theoretical Analysis}

\author{
Mohammad Ghozali ${ }^{1}$ \\ Nor 'Azzah Kamri'
}

\begin{abstract}
Issues of inefficiency and integrity at work show the increasingly demand on quality and professionalism. However, professionalism itself does not enough to produce a quality output. It must be accompanied by an Islamic personality. The combination of Islamic personality and professionalism is believed to contribute a maximum impact on the work quality. This article attempts to examine the concept of personality from Islamic perspective, its relation with professionalism and their implications in the employment context. For that purpose, qualitative study was
\end{abstract}

1 Ph.D Candidate, Department of Shariah and Management, Academy of Islamic Studies, University of Malaya, Kuala Lumpur; Senior Lecturer, Department of Shariah and Economic, Universiti Darussalam of Gontor Ponorogo, ghozali. umm@gmail.com

2 Senior Lecturer, Department of Shariah and Management, Academy of Islamic Studies, University of Malaya, Kuala Lumpur, azzah@um.edu.my 
carried out on the relevant literatures. Based on literatures, the study found that there is a close relationship between Islamic personality and professionalism. Thus, both Islamic personality and professionalism should be given attention because it provides positive implications on work quality in the organization.

Keywords: Islamic personality, professionalism, work

\section{PENDAHULUAN}

Keperluan kepada pengurusan yang berkualiti dan profesional dilihat agak menonjol akhir-akhir ini. Ia merupakan refleksi kepada perkembangan masyarakat yang semakin prihatin dan peka terhadap hak mereka sebagai pengguna yang menuntut kepada sistem perkhidmatan dan kualiti kerja yang profesional. Realitinya, pelbagai teori dan konsep moden telah diperkenalkan bagi mencapai profesionalisme dalam pekerjaan. Namun, sehingga kini masih berlaku pelbagai bentuk kelemahan dan kepincangan dalam perkhidmatan dan pengurusan masa kini. Indeks persepsi rasuah (CPI), statistik kadar rasuah, kes salah laku moral, indeks prestasi, indeks akauntabiliti dan jumlah aduan pelanggan merupakan antara indikator kepada kelemahan dan kepincangan tersebut. $^{3}$

Isu-isu ini memberi petanda bahawa sudah sampai masanya aspek pekerjaan dan pengurusan dihubungkaitkan kembali kepada Islam. Islam sebagai al-dīn memastikan segala aspek kehidupan manusia dicakupi dengan sumber, prinsip dan pendekatan pelaksanaan yang fleksibel lagi komprehensif. Selain itu, fenomena kebangkitan Islam di Malaysia pada pertengahan abad ke-20 sedikit sebanyak turut menjadi momentum kepada perubahan sikap dan persepsi masyarakat terhadap agama. Fenomena ini telah meningkatkan kesedaran dan komitmen masyarakat terhadap Islam sama ada dalam ruang lingkup ibadah, muamalah mahupun akhlak Islam, termasuklah dalam konteks pekerjaan.

Artikel ini secara khusus akan membincangkan perihal keperibadian Islam yang diyakini menjadi asas yang signifikan kepada pembentukan profesionalisme dalam diri pekerja Muslim. Kombinasi antara keperibadian Islam dan profesionalisme ini seterusnya akan memberi impak kepada kualiti pekerjaan serta membawa manfaat kepada ummah sejagat.

$3 \quad$ Muhammad Ismail Y.M. Karebet W., Menggagas Bisnis Islami (Jakarta: Penerbit Gema Insani Press, 2002), 15; Muhammad Ismail Y.M. Karebet W., Manajemen Strategis Presfektif Islam (Jakarta: Penerbit Khayr al-Bayan, 2003), 53. 


\section{KEPERIBADIAN ISLAM}

Dalam membincangkan tentang keperibadian Islam, terlebih dahulu perlu difahami konsep personaliti secara umum. Personaliti merupakan satu perkataan yang sering digunakan apabila menggambarkan diri sendiri dan orang lain. Personaliti berasal daripada perkataan Latin iaitu persona, yang merujuk kepada topeng yang digunakan oleh pelakon dalam pementasan drama. ${ }^{4}$ Biasanya personaliti diberi definisi mengikut kecenderungan masyarakat. Sesetengah masyarakat menganggap seseorang yang berpersonaliti baik adalah seseorang yang mengagumkan orang lain dengan kebolehannya bergaul dan berinteraksi dengan baik. Ada pula menganggap personaliti yang baik apabila seseorang menunjukkan tingkah laku yang bersopan santun dan bercakap dengan lemah lembut. $^{5}$

Teori personaliti yang dikemukakan oleh Carl Jung, menyatakan tingkah laku manusia dipengaruhi oleh peristiwa-peristiwa yang berlaku dan juga aspirasi masa depan. ${ }^{6}$ Pembentukan personaliti individu bukan sahaja kesan daripada peristiwa yang berlaku semasa zaman kanak-kanak tetapi juga ramalan itu merupakan kejadian ataupun aspirasi pada masa depan. ${ }^{7}$ Menurut pandangan Adler pula, personaliti itu pada dasarnya adalah kelakuan dan perasaan inferior yang wujud apabila individu, sama ada secara langsung ataupun tidak, membandingkan dirinya dengan orang lain dan mendapati dirinya lebih rendah. Bagi mengelak perasaan rendah diri daripada terus menghantui, asas keyakinan diri yang kukuh perlu dibina. Hanya dengan keyakinan diri yang tinggi dapat membekalkan tenaga bagi mengubah tingkah laku yang bersifat inferior. ${ }^{8}$

Personaliti merupakan ciri-ciri yang mensifatkan seseorang individu dan membezakannya daripada individu yang lain. Personaliti merangkumi gaya hidup, kepercayaan harapan, nilai, motif, pemikiran, perasaan, budi pekerti,

$4 \quad$ Schultz, D. \& Schultz, S.E., Theories of Personality (USA: Wadsworth, Thomson Learning, 2001), 8.

5 Schultz \& Schultz, Theories of Personality, 8.

6 Hall, C.S. \& Lindzey, G., Introduction to Theories of Personality (Canada: John Wiley \& Co., 1985), 10.

7 Shahabuddin Hashim \& Rohizani Yaakup, Teori Personaliti Perspektif Islam, Timur dan Barat (P. Pinang: Rhythm Industries Sdn. Bhd., 2004), 106.

8 Adler, A., The Neurotic Constitution: Outline of a Comparative Individualistic Psychology and Psychotherapy (New York: John Wiley \& Sons, 1985), 9; Shahabuddin Hashim \& Rohizani Yaakup, Teori Personaliti Perspektif Islam, Timur dan Barat, 145. 
persepsi, tabiat, sikap dan watak seseorang. ${ }^{9}$ Personaliti menurut pandangan Maddi dalam bukunya Personality Theories: A Comparative Analysis adalah seperti berikut;
"Personaliti adalah satu set kestabilan kecenderungan dan sifat yang menentukan mereka, persamaan dan perbezaan dalam perilaku psikologi manusia (fikiran, perasaan, dan tindakan) yang mempunyai kesinambungan dalam masa dan yang mungkin tidak mudah difahami sebagai hasil tunggal dari cabaran sosial dan biologi.", 10

Berdasarkan beberapa takrifan personaliti di atas menggambarkan bahawa personaliti merupakan corak daripada tingkah laku manusia yang berasal dalam diri individu. ${ }^{11}$ Pelbagai tingkah laku yang terjadi pada manusia berasal daripada manusia itu sendiri, sehingga yang menjadikan ukuran adalah diri individu sendiri dalam setiap tingkah laku yang diperbuat oleh manusia.

Secara keseluruhannya, para pengkaji bersepakat mengatakan bahawa personaliti merupakan ciri-ciri yang dinamik dan tersusun dimiliki oleh seseorang yang secara unik mempengaruhi kognitif, motivasi dan tingkah lakunya dalam pelbagai situasi. ${ }^{12}$ Ia juga boleh dianggap sebagai pembinaan psikologi dengan melibatkan latar belakang genetik (kecuali kepada kembar seiras) yang unik, sejarah pembelajaran dan faktor-faktor mempengaruhi sebagai respon terhadap persekitaran.

Dalam bahasa Arab, personaliti atau keperibadian disebut al-syakhșiyyah. Ia berasal daripada kata syakhșun yang bermaksud orang, seseorang atau peribadi. ${ }^{13}$ Keperibadian juga merujuk kepada jati diri seseorang (haqiquah alsyakhși).

Menurut Taqī al-Dīn al-Nabhān̄̄ dalam kitabnya al-Syakhșiyyah alIslämiyyah, keperibadian seseorang ditentukan oleh cara berfikir (al-'aqliyyah) dan cara berperilaku (nafsiyah). Cara berfikir merujuk kepada cara seseorang

$9 \quad$ Yong Gan Chok, 'Persepsi Pelajar Tingkatan Dua dan Empat terhadap Ciri-Ciri Personaliti dan Kemahiran Guru Bimbingan dan Kaunseling di Dua Buah Sekolah Daerah Petaling' (Disertasi Sarjana, Universiti Malaya, 2003), 27.

10 Maddi, Salvatore R., Personality Theories: A Comparative Analysis (California USA: Books/Cole Publishing Company, Pasific Grove. 1994), 8.

11 Burger, Jerry M., Personality Theory and Research (USA California: Wadsworth Publishing Company, Belmont, 1986), 9; Shahabuddin Hashim \& Rohizani Yaakup, Teori Personaliti Perspektif Islam, Timur dan Barat, 145.

12 Ryckman, M.R, Theories of Personality (USA: Wadswort/Thomson Learning Co., 2000), 1 .

13 Ahmad Warson Munawwir, al-Munawwir (Surabaya: Penerbit Pustaka Progresif, 1997), 700. 
memikirkan sesuatu mengikut suatu standard tertentu atau bagaimana seseorang mengaitkan fakta dengan maklumat sebelumnya (dan sebaliknya) berdasarkan suatu standard tertentu. Manakala cara berperilaku merujuk kepada tindakan untuk memenuhi keperluan dan keinginannya. ${ }^{14}$

Keperibadian adalah sesuatu yang abstrak untuk diekspresikan. Ia hanya dapat dinilai dan dirasai melalui kesan yang ditimbulkan daripada keperibadian yang ditonjolkan. Justeru, ada yang melihat keperibadian sebagai suatu sifat khas yang dimiliki oleh seseorang yang berbeza daripada orang lain. ${ }^{15}$ Perkembangan ilmu pengetahuan pada abad ke-18 telah menyebabkan kajian tentang sifat manusia berubah akhirnya menjadi psikologi yang mengkaji tentang perilaku manusia. Pakar psikologi hari ini terus giat dalam membahaskan kajian tentang keperibadian, yang meliputi sifat seseorang, genetik dan tindakan. ${ }^{16}$ Cara berfikir dan perilaku seseorang membuktikan jenis keperibadian yang diekspresikan melalui perbuatannya. Cara berfikir ditentukan oleh maklumat yang diperolehi, manakala perilaku seseorang ditentukan oleh sesuatu idea yang mereka fahami.

Islam telah memberikan jalan penyelesaian bagi umat Islam untuk membentuk diri mereka sendiri dengan keperibadian tertentu yang berbeza dengan orang lain (bukan Islam). Perbezaan tersebut ada kerana asas yang digunakan adalah berbeza. Keperibadian Muslim dibina atas akidah Islam sebagai asas pembinaan mentaliti yang bersandar kepada ajaran agama Islam. $^{17}$

Menurut 'Umar Sulayman al-Asqar, keperibadian Islam merujuk kepada keperibadian seorang Muslim dari masa ke masa, sejak adanya para nabi-nabi dan rasul-rasul dan pengikutnya sampai sekarang. ${ }^{18}$ Beliau membahagikan beberapa kumpulan keperibadian seorang Muslim iaitu, keperibadian yang lurus (benar), keperibadian yang tidak ternoda, keperibadian sepanjang abad, bahagian-bahagian yang membentuk keperibadian Muslim dan ciri-ciri keperibadian Muslim. ${ }^{19}$

14 Taqī al-Dīn al-Nabhānī, al-Syakhṣiyyah al-Islāmiyyah, vol. I (Beirūt: Dār alUmmah, 1994), 54.

15 Taqiy al-Dīn al-Nabhān̄̄, al-Syakhșiyyah al-Islāmiyyah, vol. I, 54

16 Yadi Purwanto, Etika Profesi Psikologi Profetik Perspektif Psikologi Islam (Bandung: Penerbit PT Refika Aditama, 2007), 1415.

17 Muhammad Ismail Y, M. Karebet W, Menggagas Bisnis Islami, 21.

18 'Umar Sulayman al-Asqar, Maqāṣid al-Mukallifìn, al-Niyah fì al- 'Ibādāt (Jordan: Dār al-Nafā'is li al-Nasyr wa al-Tawzi', cet. V, 1999), 52.

19 'Umar Sulayman al-Asqar, Maqāṣsid al-Mukallifìn, al-Niyah fì al-'Ibādāt, 10. 
Pada masa yang sama, Islam mengambilkira tindakan manusia yang asal daripada naluri semula jadi dan peraturan syariah yang berasal daripada aqidah itu sendiri. Peraturan Syariah menetapkan bahawa penyertaan naluri manusia dengan setiap perilaku merupakan pilihan setiap individu Muslim yang hidup di dunia ini. Seorang Muslim sewajarnya menyelaraskan naluri yang pelbagai secara bersama tanpa meninggalkan peraturan bagi memenuhi kepuasan naluri. Untuk itu, peraturan Syariah sama ada membenarkan atau tidak perlu dilihat terlebih dahulu. ${ }^{20}$

Jadi kesimpulannya, keperibadian Islam merujuk kepada setiap perilaku yang dilakukan individu Muslim dalam hidup ini di mana naluri individu Muslim disesuaikan dengan ketetapan Syariah.

\title{
PEMBENTUKAN KEPERIBADIAN ISLAM
}

Dalam berbuat sesuatu ataupun menyelesaikan permasalahan yang dihadapi, seseorang itu tidak terlepas daripada maklumat yang masuk pada akal fikirannya. Menurut al-Taqī al-Dīn al-Nabhān̄i;

\begin{abstract}
"Keperibadian setiap manusia terbentuk daripada pola fikir ('aqliyah) dan pola sikap (nafsiyah). Keperibadian tidak ada kaitannya dengan bentuk tubuh, aksesori dan seumpamanya. Semua itu hanya (penampakan) kulit luar belaka yang merupakan kedangkalan berfikir bagi orang yang menganggap aksesori sebagai salah satu faktor pembentukan keperibadian atau mempengaruhi keperibadian. " 21
\end{abstract}

Manusia mempunyai keistimewaan disebabkan akalnya. Justeru, perilaku seseorang menunjukkan tinggi rendahnya akal seseorang, kerana perilaku seseorang bergantung kepada persepsi (mafāhim). Dengan kata lain, tingkah laku individu berkait rapat dengan persepsinya dan tidak boleh dipisahkan." 22

Pola fikir adalah cara yang digunakan untuk memikirkan sesuatu; iaitu cara mengeluarkan keputusan hukum tentang sesuatu, mengikut kaedah tertentu yang diimani dan diyakini seseorang. Ketika seseorang memikirkan sesuatu

\footnotetext{
$20 \quad$ Muhammad Ismail Y.M.Karebet W., Manajemen Strategis Presfektif Islam, xiii.

21 Al-Ghazālī, al-Tibr al-Masbūk fì Naṣihāh al-Muluk (Syirkah al-Ṭaba'ah alā Fanniyah al-Mutahidah, 1967), 11.

22 Taq̄īal-Dīn al-Nabhān̄i, al-Syakhṣiyyah al-Islāmiyyah (Beirūt: Dār al-Ummah, cet. vi, 2003), 9; 'Alī Sami al-Nasyar, Manāhij al-Baḥth 'inda Mufakkīr al-Islāmiyyah (Dār al-Ma'ārif, 1978), 36.
} 
untuk mengeluarkan keputusan yang bersandarkan kepada aqidah Islam, maka pola fikirnya merupakan pola fikir Islam ( 'aqliyah al-Islāmiyyah). Manakala pola sikap adalah cara yang digunakan seseorang untuk memenuhi tuntutan naluri (gharizzah) dan keperluan jasmani (hājah al-'uḍāwiyyah) iaitu usaha memenuhi kedua-dua tuntutan tersebut mengikut kaedah yang diimani dan diyakininya.

Perbuatan manusia pada hakikatnya merupakan suatu bentuk pemenuhan keperluan manusia berteraskan dorongan yang lahir daripada keperluan jasmani (al-hajah al-'ud̄ōwiyyah) dan naluri (gharizah). Sebagai contoh, aktiviti pekerjaan yang dilakukan oleh manusia adalah sebagai memenuhi naluri mempertahankan diri (gharizzah al-baqā'), sama ada untuk mempertahankan diri agar tetap dapat hidup, mahupun untuk meningkatkan kualiti kehidupan secara material. Jika keperluan naluri dan keperluan jasmani tersebut dilaksanakan dengan sempurna mengikut akidah Islam, maka pola sikapnya dinamakan pola sikap Islam (al-nafsiyah al-Islāmiyyah). ${ }^{23}$

Justeru itu, jika kaedah yang digunakan untuk pola fikir dan pola sikap seseorang adalah bersumberkan al-Quran mahupun al-Hadith, maka keperibadian (syakhșiyyah) pasti merupakan keperibadian Islam (syakhșiyyah Islāmiyyah). Dengan kata lain, apabila seseorang menjadikan akidah Islam sebagai asas bagi pola fikir dan pola sikapnya, maka akan lahirlah keperibadian Islam.

Pembentukan keperibadian Islam tidak memadai dengan hanya memilih pola fikir Islam semata-mata. Mereka yang memiliki pola fikir Islam hanya boleh mengeluarkan keputusan sesuai dengan hukum syarak, sehingga mereka mampu menggali hukum, undang-undang, mengetahui halal dan haram, memiliki kesedaran ${ }^{24}$ dan pemikiran yang matang, mampu menyatakan hujah yang kuat dan tepat, serta mampu menganalisis pelbagai perbuatan dengan betul. ${ }^{25}$ Namun semua itu belum cukup, pola sikapnya juga perlu mempamerkan pola sikap Islam, di mana mereka boleh memenuhi tuntutan naluri dan keperluan jasmaninya berlandaskan Islam. Mereka mengerjakan suatu aktiviti yang halal dan menjauhi yang haram, berada dalam kedudukan yang disukai Allah SWT, mendekatkan diri kepada-Nya melalui apa sahaja yang telah difardhukan, serta berkeinginan kuat untuk mengerjakan amalan

23 Taqī al-Dīn al-Nabhān̄̄, al-Syakhșiyyah al-Islāmiyyah, 9.

24 Al-Ghazālī, Ma 'ārij al-Quds fì Madārij Ma rrifāt al-Nafs (Qāhirah: Maktabah alJundi, 1968), 27.

25 Muhammad Husayn 'Abd Allāh, Mafāhim al-Islāmiyyah, al-Rūh, al-Idrāk, al'Amāl, al-Syakhșiyyah (Beirūt: Dār al-Bayāriq, cet. 1, 1996), 184-185; Muhammad Muḥammad Ismā’̄̄l, al-Fikr al-Islāmī (Beirūt: Maktabah al-Wa’iy, 1985), 16. 
sunnah hingga mereka makin bertambah dekat dengan Allah SWT. Mereka sentiasa bersikap benar dan tulus, memerintahkan yang ma' $r u \bar{f} f$, mencegah kemungkaran, mencintai dan membenci kerana Allah, dan sentiasa bekerja dengan cerminan akhlak yang baik.

Dalam keadaan yang lain, adalah tidak cukup jika hanya pola sikapnya merupakan pola sikap Islam, sementara pola fikirnya tidak. Ini mengakibatkan mereka beribadah kepada Allah dengan kebodohan, yang menyebabkan pelakunya tersesat dari jalan yang lurus. Misalnya, berpuasa pada hari yang diharamkan, sembahyang pada waktu yang dimakruhkan dan bersikap lemah terhadap orang yang melakukan kemungkaran, bermuamalah dan bersedekah dengan riba, dengan anggapan mendekatkan diri kepada Allah. Dengan kata lain, mereka telah melakukan kesalahan tapi menyangka telah melakukan kebajikan. Akibatnya, mereka memenuhi tuntutan naluri dan keperluan jasmani yang tidak sesuai dengan perintah Allah SWT dan Rasul-Nya.

Sesungguhnya keperibadian Islam tidak akan berjalan dengan lurus, kecuali jika pola fikir individu tersebut merupakan 'aqliyah al-Islāmiyyah, yang mengetahui dan menambah ilmu-ilmu Syariah sesuai dengan kemampuannya. Pada masa yang sama, pola sikap individu tersebut juga merupakan al-nafsiyah al-Islämiyyah sehingga dia melaksanakan ilmu yang diketahui dalam segala urusannya, baik dengan Penciptanya, mahupun dengan dirinya sendiri, sesuai dengan cara yang disukai dan diredhai oleh Allah SWT. ${ }^{26}$

Dengan ini, dapat dirumuskan bahawa pembentukan keperibadian Islam adalah berasaskan kepada pola fikir Islam (al-'aqliyah al-Islāmiyyah) dan pola sikap Islam (al-nafsiyah al-Islämiyyah) yang menatijahkan kecenderungan kepada kefahaman Islam (mafhūm Islām $\vec{\imath}$ ) dan perbuatan Islam ( 'amal Islām $\vec{\imath}$ ) yang berlandaskan aturan-aturan Islam (al-niz̄ām al-Islāmiyyah). ${ }^{27}$ Rajah 1 berikut mengilustrasikan pembentukan keperibadian Islam berdasarkan perbincangan di atas.

Taqī al-Dīn al-Nabhānī, al-Syakhșiyyah al-Islāmiyyah, 10.

27 Hafidz Abdurrahman, Islam, Politik dan Spiritual (Singapore: Lisan al-Haq, 1998), 23. 
Rajah 1: Pembentukan Keperibadian Islam.

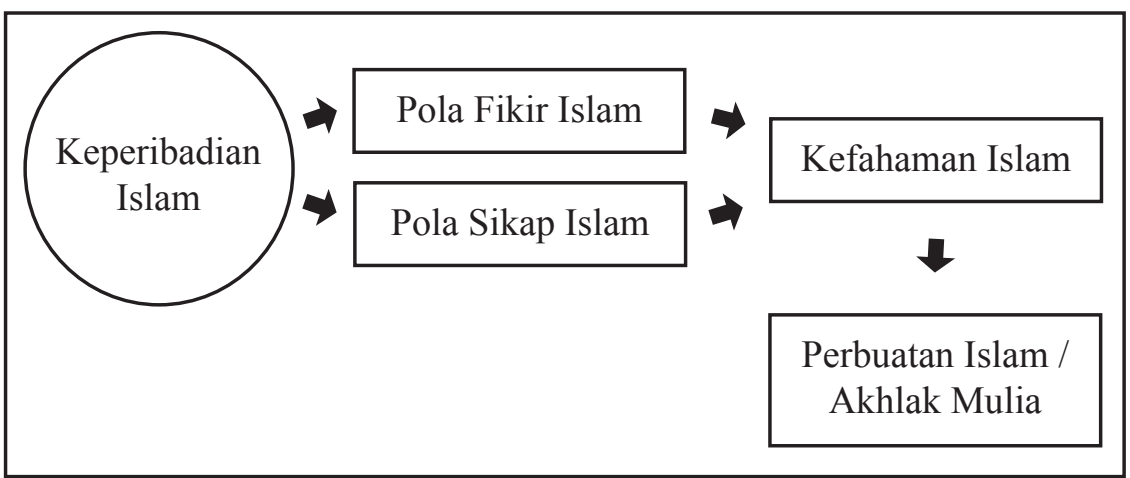

Sumber: Diubah suai daripada Muhammad Husayn 'Abd Allāh. ${ }^{28}$

\section{CIRI-CIRI KEPERIBADIAN ISLAM}

Al-Quran dan hadith merupakan sumber utama yang harus dirujuk oleh setiap Muslim dalam segala aspek kehidupan. Keperibadian Islam yang dikehendaki al-Quran dan Hadith adalah keperibadian Islam yang khusus dan tidak sama dengan agama lain. Keperibadian Islam ini boleh dilihat menerusi sikap, ucapan dan perilaku yang berasaskan ketetapan syariah dari Allah SWT dan Rasulullah SAW. ${ }^{29}$

Tidak dinafikan persepsi masyarakat yang melihat keperibadian Islam antara individu adalah berbeza-beza ada benarnya. Namun, secara keseluruhannya dapat dirumuskan keperibadian Islam itu memiliki sepuluh karakter atau ciri khas yang mesti ada pada seorang Muslim sebagaimana yang dikemukakan oleh Hasan al-Banna dalam kitabnya Majmū 'ah al-Rasaīl li al-Imām al-Syāhid Hasan al-Banna:

\section{Salīm al-'Aqīdah (aqidah yang murni) ${ }^{30}$}

Salīm al-'Aqīdah merupakan satu kemestian pada setiap Muslim. Dengan akidah yang murni, seorang Muslim memiliki ikatan yang kuat kepada

28 Muhammad Ḥusayn 'Abd Allāh, Min Muqawwimāt al-Nafsiyah al-Islāmiyyah (Dār al-Bayāriq, 2004).

29 'Umar Sulayman al-Asqar, Ciri-ciri Keperibadian Muslim, 21.

30 Hasan al-Banna, Majmū'ah al-Rasā'il li al-Imām al-Syāhid Hasan al-Banna (Mesir: al-Bașā'ir wa al-Dirāsat, t.t), 438; Hasan al-Banna, Risalah Pergerakan Ikhwan al-Muslimin, terj. (Solo: Penerbit Era Intermedia, 2000), 168-169. 
Allah SWT. Ikatan tersebut sebagai manifestasi pekerjaan yang menjadi tanggungjawabnya agar tidak menyimpang dari jalan dan ketentuan-ketentuan Syariah. Dengan kemurnian dan kemantapan akidah, seorang Muslim akan menyerahkan segala perbuatannya kepada aturan-aturan Allah. Firman Allah;

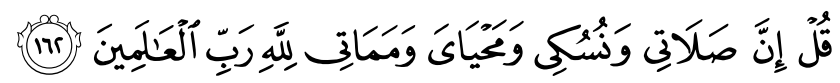

"Sesungguhnya solatku, ibadahku, hidupku dan matiku, semua bagi Allah, Tuhan semesta alam.”

(Surah al-An'ām, 6:162)

Memandangkan akidah merupakan suatu yang amat penting, maka fasa awal misi dakwah Rasulullah SAW mengutamakan pembinaan akidah, iman, tauhid, Islam dan ihsan.

\section{2. Șaḥị̣ al-'Ibādat ${ }^{31}$ (ibadah yang benar)}

Saḥ̄h al-'Ibādat merupakan salah satu perintah Allah dalam al-Quran yang sangat penting. Setiap aktiviti kehidupan manusia di dunia ini terikat dengan aturan Allah SWT, tanpa ada pengecualian sama ada aktiviti pekerjaan atau aktiviti lainnya. Firman Allah;

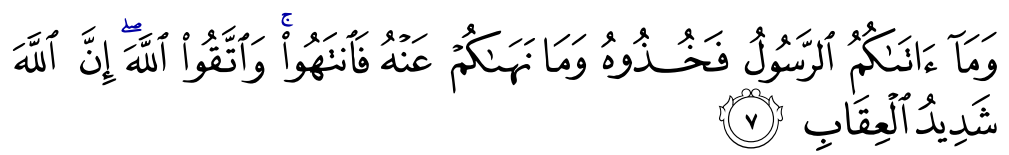

"Apa yang diberikan Rasul kepadamu maka terimalah dia. Dan apa yang dilarangnya bagimu maka tinggalkanlah; dan bertakwalah kepada Allah. Sesungguhnya Allah sangat keras hukumanNya."

(Surah al-Hasyr, 59:7)

Justeru itu, seorang Muslim yang memiliki keperibadian Islam perlu memastikan setiap aktiviti pekerjaannya haruslah dalam ruang lingkup ibadah yang benar sebagaimana yang termaktub dalam al-Quran dan Hadith Rasulullah SAW.

\section{Matīn al-Khuluq ${ }^{32}$ (akhlak yang kukuh)}

31 Hasan al-Banna, Majmū' 'ah al-Rasā'il li al-Imām al-Syāhid Hasan al-Banna, 438; Hasan al-Banna, Risalah Pergerakan Ikhwan al-Muslimin, 168-169.

32 Hasan al-Banna, Majmū 'ah al-Rasā' il li al-Imām al-Syāhid Hasan al-Banna, 438; Hasan al-Banna, Risalah Pergerakan Ikhwan al-Muslimin, 168-169. 
Matīn al-Khuluq merupakan sikap dan perilaku yang mesti dimiliki oleh setiap Muslim, baik dalam hubungannya dengan Allah SWT mahupun hubungan sesama makhluk. Dengan akhlak yang mulia, manusia akan bahagia dalam hidupnya, di dunia dan akhirat. Dalam konteks pekerjaan, setiap individu yang memiliki keperibadian Islam mestilah tidak meninggalkan tanggungjawab pekerjaan, jujur, amanah, ikhlas dan tekun menunaikan tanggungjawab. Dalam hal ini, keunggulan akhlak Rasulullah wajar dicontohi sehingga ianya diabadikan oleh Allah SWT di dalam al-Quran:

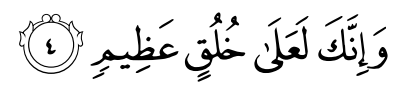

"Dan sesungguhnya kamu benar-benar memiliki akhlak yang agung."

(Surah al-Qalam, 68:4)

\section{Qawiyy al-Jism ${ }^{33}$ (kekuatan jasmani)}

Qawiyy al-Jism bererti seorang Muslim memiliki daya kekuatan tubuh sehingga dapat melaksanakan tugas pekerjaannya sesuai dengan ajaran Islam secara maksimum dengan fizikal yang kuat. Bekerja merupakan salah satu amalan fizikal di dalam Islam yang mesti dilaksanakan dengan keadaan fizikal yang sihat dan kuat. Oleh kerana itu, kesihatan jasmani mesti menjadi keutamaan bagi seorang Muslim dan untuk mencegahnya daripada jangkitan penyakit. Dalam hal ini, Rasulullah SAW pernah bersabda;

$$
\text { المؤمن القوي خير وأحب إلى الله من المؤمن الضعيف }
$$

"Mukmin yang kuat lebih baik dan lebih dicintai Allah daripada mukmin yang lemah." 34

\section{Muthaqqaf al-Fikr ${ }^{35}$ (intelek dalam berfikir)}

Muthaqqaf al-Fikr iaitu fikiran yang berpengetahuan, menampakkan suatu kemuliaan manusia yang diberi oleh Allah berbanding dengan makhluk lain iaitu berupa akal. Ia juga salah satu cerminan sifat Rasul iaitu fațānah

33 Hasan al-Banna, Majmū 'ah al-Rasā'il li al-Imām al-Syāhid Hasan al-Banna, 438; Hasan al-Banna, Risalah Pergerakan Ikhwan al-Muslimin, 168-169.

34 Muslim, Șah̄h Muslim, Kitāb al-Qadr, Bāb fĩ al-Amr bi al-Quwwah wa Tark al'Ajz wa al-Isti'ānah billāh wa Tafwiọ al-Maqādir lillāh, no. hadith 4816 (Mesir: 'Īsā al-Bābī al-Ḥalabīi, 1970).

35 Hasan al-Banna, Majmū 'ah al-Rasā'il li al-Imām al-Syāhid Hasan al-Banna, 438; Hasan al-Banna, Risalah Pergerakan Ikhwan al-Muslimin, 168-169. 
(bijaksana). Al-Quran mengungkap ayat-ayat yang merangsang manusia untuk berfikir dan memiliki kreativiti dalam bekerja, misalnya firman Allah:

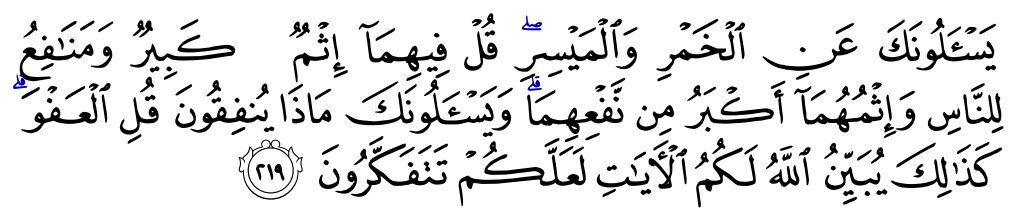

Mereka bertanya kepadamu tentang khamar dan judi. Katakanlah: "Pada kedua-duanya itu terdapat dosa besar dan beberapa manfaat bahagi manusia, tetapi dosa keduanya lebih besar daripada manfaatnya." Dan mereka bertanya kepadamu apa yang mereka nafkahkan. Katakanlah: "Yang lebih dari keperluan." Demikianlah Allah menerangkan ayat-ayat-Nya kepadamu supaya kamu berfikir.

(Surah al-Baqarah, 2: 219)

Hal ini memberi gambaran bahawa ilmu itu bukanlah pengetahuan yang terpisah dengan apa yang mempengaruhi fikiran. Dalam Islam, tidak ada satu pun perbuatan yang mesti dilakukan, kecuali dimulakan dengan aktiviti berfikir. ${ }^{36}$ Oleh itu, seorang Muslim mestilah memiliki wawasan keislaman dan keilmuan yang luas bagi memenuhi setiap ajaran Islam dan hikmah di sebaliknya.

\section{Mujāhidan linafsih ${ }^{37}$ (berjuang melawan hawa nafsu)}

Mujāhidan linafsih merupakan salah satu keperibadian yang mesti ada pada peribadi seorang Muslim kerana setiap manusia memiliki kecenderungan pada yang baik dan buruk. Melaksanakan kecenderungan yang baik dan menghindari yang buruk menuntut kesungguhan. Kesungguhan itu hanya ada apabila seseorang berjuang melawan hawa nafsu. Hawa nafsu yang ada pada setiap diri manusia mestilah diusahakan agar tunduk pada ajaran Islam. Firman Allah SWT:

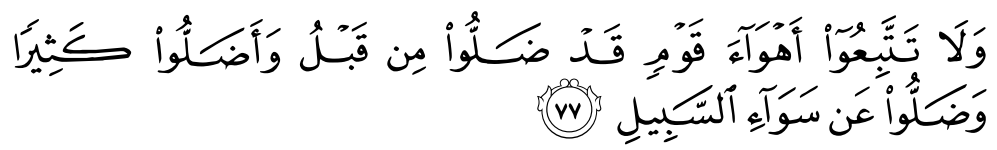

\footnotetext{
36 Sayyid Quțub, Fi Zilāl al-Qur'ān, vol. 10 (Beirūt: Dār al-Syuruq, 1412 H), 70.

37 Hasan al-Banna, Majmū 'ah al-Rasā'il li al-Imām al-Syāhid Hasan al-Banna, 438; Hasan al-Banna, Risalah Pergerakan Ikhwan al-Muslimin, 168-169.
} 
"Dan janganlah kamu mengikuti keinginan orang-orang yang telah tersesat dahulu dan (telah) menyesatkan banyak (manusia), dan mereka sendiri tersesat dari jalan yang lurus."

(Surah al-Mā'idah, 5: 77)

Berdasarkan ayat ini difahami bahawa perbuatan mengikuti hawa nafsu dalam kalangan orang-orang yang tidak berpengetahuan adalah dilarang, yakni agama dan pendapat suatu kaum yang telah tersesat jauh dari jalan hidayah yang lurus dan mereka telah menyesatkan banyak manusia dari kebenaran. ${ }^{38}$

\section{Härrișan 'alā Waqtih' ${ }^{39}$ (menjaga waktu)}

Hārișan 'alā Waqtih merupakan faktor penting bagi manusia. Masa memperoleh perhatian yang besar daripada Allah dan Rasul-Nya. Allah SWT banyak bersumpah di dalam al-Quran dengan menyebut nama masa seperti wa al-fajr, wa al-duhā, wa al-'așr, wa al-layl dan seterusnya. Allah SWT memberikan waktu kepada manusia dalam jumlah yang sama, iaitu 24 jam sehari semalam. Dengan masa 24 jam itu, ada manusia yang beruntung dan ada manusia yang rugi sebagaimana firman Allah;

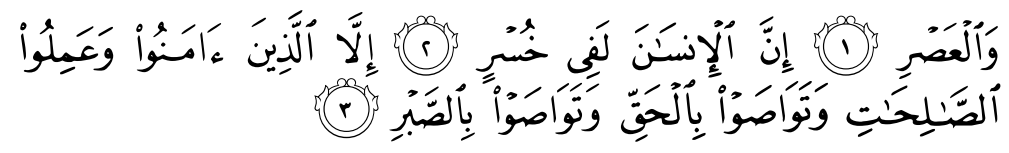

"Demi masa! Sesungguhnya manusia itu dalam kerugian. Kecuali orang-orang yang beriman dan beramal soleh, dan mereka pula berpesan-pesan dengan kebenaran serta berpesan-pesan dengan sabar."

(Surah al-'Așr, 103: 1-3)

Oleh kerana itu, setiap Muslim yang berkeperibadian Islam amat dituntut untuk bijak mengurus masanya dengan penggunaan masa yang efektif, dan tidak disia-siakan. Nabi SAW turut menekankan kepentingan masa melalui pelaksanaan lima perkara sebelum datang lima perkara, iaitu masa hidup sebelum mati, sihat sebelum sakit, muda sebelum tua, lapang sebelum sibuk dan kaya sebelum miskin.

\footnotetext{
38 Sayyid Quțub, Fī Zilāl al-Qur'ān, vol. 3, 168.

39 Hasan al-Banna, Majmū 'ah al-Rasā'il li al-Imām al-Syāhid Hasan al-Banna, 438; Hasan al-Banna, Risalah Pergerakan Ikhwan al-Muslimin, 168-169.
} 


\section{Munažzaman fì Syu'ūnih ${ }^{40}$ (teratur dalam urusan)}

Munazzaman fì Syu'ünih termasuk antara ciri-ciri keperibadian Islam. Oleh kerana itu, aspek 'ubudiyyah mahupun muamalah mesti diselesaikan dan dilakukan dengan baik. Apabila suatu urusan diamalkan secara bersama-sama, teratur dan sistematik, maka ianya dapat dilaksanakan secara profesional. Bersungguh-sungguh, bersemangat dan teratur merupakan antara yang mesti mendapat perhatian serius dalam pelaksanaan tugas atau kerja. Firman Allah SWT;

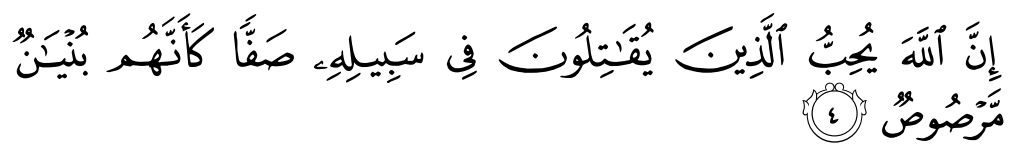

"Sesungguhnya Allah mengasihi orang-orang yang berperang untuk membela agama-Nya dalam barisan yang teratur rapi, seolah-olah mereka sebuah bangunan yang tersusun kukuh."

(Surah al-Șaff, 61:4)

\section{Qādiran 'alā al-Kasb ${ }^{41}$ (kemampuan berusaha sendiri/berdikari)}

Qādiran 'alā al-Kasb merupakan sesuatu yang sangat diperlukan oleh seorang Muslim yang berjuang menegakkan kebenaran. Begitu juga dalam konteks pekerjaan di mana hanya mereka yang berdikari berupaya merealisasikan perintah bekerja mencari nafkah dan mempersiapkan masa depan yang baik. Firman Allah SWT:

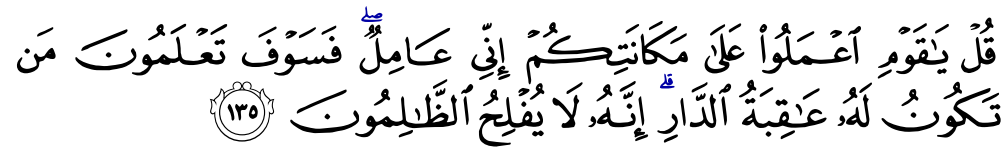

Katakanlah: "Hai kaumku, berbuatlah sepenuh kemampuanmu, sesungguhnya akupun berbuat (pula). Kelakmu akan mengetahui, siapakah (di antara kita) yang akan memperoleh hasil yang baik dari dunia ini. Sesungguhnya orang yang zalim itu tidak akan mendapat keberuntungan."

(Surah al-An'ām, 6:135)

\footnotetext{
40 Hasan al-Banna, Majmū 'ah al-Rasā'il li al-Imām al-Syāhid Hasan al-Banna, 438; Hasan al-Banna, Risalah Pergerakan Ikhwan al-Muslimin, 168-169.

41 Hasan al-Banna, Majmū 'ah al-Rasā'il li al-Imām al-Syāhid Hasan al-Banna, 438; Hasan al-Banna, Risalah Pergerakan Ikhwan al-Muslimin, 168-169.
} 


\section{Näfi'an li ghayrih ${ }^{42}$ (bermanfaat untuk orang lain)}

Näfi 'an li ghayrih merupakan suatu tuntutan kepada peribadi Muslim. Manfaat yang dimaksudkan ialah manfaat yang baik sehingga di manapun dia berada, orang di sekitarnya sentiasa merasai keberadaannya. Ini bererti individu yang berkeperibadian Islam mesti selalu berfikir, mempersiapkan diri dan berupaya semaksimum mungkin untuk memberi manfaat dan mengambil peranan yang baik dalam khalayak masyarakat. Dalam kaitan inilah, Rasulullah SAW bersabda:

$$
\begin{aligned}
& \text { خير الناس أنفعهم للناس } \\
& \text { "Sebaik-baik manusia adalah yang paling bermanfaat bagi } \\
& \text { orang lain." } 43
\end{aligned}
$$

\section{PROFESIONALISME ISLAM}

Lazimnya, seorang dikatakan profesional jika dia mahir dalam bidang pekerjaannya di mana ia mendapatkan pencapaian/pendapatan hasil daripada dia bekerja. ${ }^{44}$ Dengan kata lain, pekerjaan itu didasari dengan kemahiran yang dimiliki oleh setiap peribadi pelaku pekerja.

Profesionalisme lebih mengarah pada jiwa, sikap, watak, semangat dan nilai yang dimiliki oleh seorang yang profesional. Tanpa profesionalisme, sebuah organisasi tidak dapat bertahan kerana profesionalisme inilah yang menghidupkan setiap aktiviti-aktiviti yang ada di dalamnya. Profesionalisme boleh diertikan sebagai kemampuan menyesuaikan diri dengan persekitaran yang cepat berubah dan menjalankan tugas dan fungsinya yang mengarah kepada pencapaian visi dan misi serta nilai-nilai organisasi. ${ }^{45}$

Berdasarakan definisi di atas dapat disimpulkan bahawa profesionalisme tidak hanya berdasarkan kemampuan yang dimiliki tetapi juga mencerminkan sikap dan nilai dalam menghadapi perubahan yang terjadi demi tercapainya tujuan organisasi. Oleh itu, pekerja yang profesionalisme merujuk kepada keahlian atau kemampuan pekerja dalam mengerjakan tugasnya, serta mampu

\footnotetext{
42 Hasan al-Banna, Majmū' 'ah al-Rasā'il li al-Imām al-Syāhid Hasan al-Banna, 438; Hasan al-Banna, Risalah Pergerakan Ikhwan al-Muslimin, 168-169.

43 Al-Suyūțī, al-Jāmi ' al-Ṣaghīr fì Ahādīth al-Bashīr wa al-Nadhīr, no. hadith 4044 (Beirūt: Dār al-Fikr, 1980).

44 'Abd al-Ḥamid Mursi, al-Syakhșiyah al-Muntajah (Mesir: Maktabah Waḥbah, 1985), 20.

45 Gibson \& Donnelly, Organizations, 8 ed. (Richard D. Irwin, Inc, 1995), 129.
} 
menyesuaikan diri terhadap perubahan persekitaran. ${ }^{46}$ Pekerja mempunyai peranan yang sangat penting dalam pencapaian tujuan organisasi. Maka mereka perlu bersemangat untuk terus belajar menambah ilmu agar mampu mendalami dan memberi respon terhadap setiap perubahan yang berlaku.

\section{DASAR PROFESIONALISME ISLAM}

Dalam Islam, profesionalisme merujuk kepada penunaian segala bentuk amanah yang telah dipertanggungjawabkan kepada seseorang dengan ikhlas untuk mendapatkan keredhaan Allah SWT dan terus berazam untuk melakukan yang terbaik lantaran menyedari pengawasan Allah adalah lebih tajam daripada pengawasan manusia. Justeru, profesional dalam Islam didasari 3 aspek utama ajaran Islam iaitu Iman, Islam dan Ihsan. ${ }^{47}$

\section{Iman sebagai Dasar Profesionalisme}

Seorang yang beriman melihat aktivitinya sebagai ibadah. Dalam konteks ibadah, semua pekerjaan tidak bertujuan untuk memuaskan pihak atasan, pelanggan, ataupun pujian manusia. Ibadah adalah pengerahan seluruh usaha dalam rangka mencapai kedudukan tertinggi di sisi Allah. Ia akan memuliakan aturan Allah dan mengutamakan pengabdian kepada Allah SWT. ${ }^{48}$

Motivasi iman menjadikan pekerjaan terasa bermakna dan mempunyai erti yang berkekalan bagi pelakunya. Pekerjaan menjadi tempat yang menyenangkan bagi menghasilkan karya terbaik. Pekerjaan dipandang sebagai tabungan untuk masa depan yang kekal abadi iaitu akhirat. ${ }^{49}$ Hal ini menjadikan seseorang bekerja penuh dengan kebersihan, jujur, bermakna, dan berorientasikan ibadah untuk mencari keredhaan Allah. ${ }^{50}$

Prinsip keimanan perlu mendasari profesionalisme. Bermula daripada membina konsep, pandangan, sikap, gaya berfikir berasaskan keimanan, sehinggalah penentuan bentuk tindakan dalam organisasi. Mereka yang beriman

46 John M, Ivancevich, Human Resource Management; Foundations of Personnel (Homewood, III: Richard D. Irwin, 1992), 170.

47 Yūsuf al-Qaraḍāwī, Khaṣāiṣ al-'Ammah li al-Islām (Qāhirah: Mu'asasah alRisālah,1989), 45.

48 Yūsuf al-Qaraḍāwī, al- 'Aql wa al- 'Ilm fì al-Qur'ān al-Karīm (Beirūt: Mu'assasah al-Risālah, 2001), 47; 'Abd al-Rahmān al-Malik, al-Siyāsah al-Iqtișādiyah alMuthlā (Bangil Jatim: al-Izzah, cet. 1, 2001), 15.

49 Lihat Surah al-Hasyr, 59:18, Surah al-A'rāf, 7:8-9.

50 Yūsuf al-Qaraḍāwī, Khașā'iṣ al- 'Āmmah li al-Islām, 46. 
akan melaksanakan segala bentuk amanah yang telah dipertanggungjawabkan kepadanya dengan ikhlas untuk mendapat keredhaan Allah dan terus berazam untuk melakukan yang terbaik lantaran menyedari pengawasan Allah adalah lebih tajam daripada pengawasan manusia. Rasa keimanan sebegini di kalangan pekerja akan membentuk impak positif ke arah melahirkan generasi dan organisasi yang profesional. ${ }^{51}$

\section{Islam sebagai Ekspresi Operasi}

Seseorang yang bekerja secara profesional akan memegang teguh syariat Islam dalam segala amalan mahdah ${ }^{52}$ ataupun ghayr mahdah. ${ }^{53}$ Ajaran Islam yang luas, mendalam, dan sempurna memberikan arahan yang pasti dan jelas, serta sesuai dengan fitrah manusia. ${ }^{54} \mathrm{Jadi}$, tidak ada yang dapat dipisahkan dari ajaran Islam.

Dalam konteks pekerjaan, Islam menuntut setiap manusia bekerja, berusaha mencari rezeki untuk keperluan diri dan keluarga. Islam juga menyatakan bahawa sesuatu kerja, usaha, ataupun perniagaan yang halal itu merupakan tugas yang diamanahkan oleh Allah kepada manusia. Maka apabila seseorang itu menjalankan tugasnya ataupun bekerja, dengan sendirinya bererti bahawa seseorang itu sedang menunaikan amanah Allah. Setiap kerja yang halal diredhai oleh Allah dan disertai dengan niat sebagai ibadat. ${ }^{55}$ Firman Allah SWT:

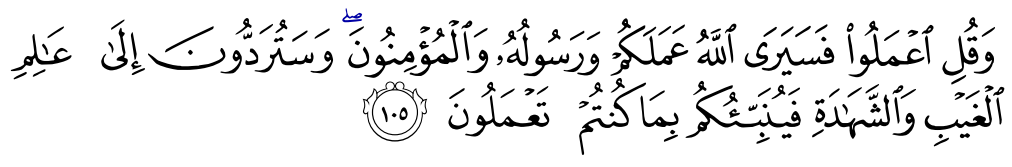

51 Lihat kupasan lanjut dalam al-Ghazālī, Ihyā' 'Ulūm al-Dīn, vol. 3 (Damsyik: Dār alKhayr, 1990), 177; Nor 'Azzah Kamri, 'Etika Pengurusan Islam dan Konvensional: Satu Analisis Perbandingan', Jurnal Syariah 10/2 (2002): 43-66, Mohd. Affandi Hassan, The Tawhidic Approach in Management and Public Administration (Kuala Lumpur: INTAN, 1992), 57.

52 Ibadah mahdah adalah ibadah yang memiliki sifat tawqifi (telah ditetapkan) oleh Allah dan Rasulullah sampai dalam persoalan terperinci sama ada waktu, jumlah, tempat, amalan (bacaan) ataupun yang lain.

53 Ibadah ghayr mahdah adalah ibadah yang telah ditetapkan tasyri " namun tentang waktu, tempat atau amaliyahnya ditentukan mengikut pelaksanaan aktiviti manusia masing-masing.

54 Bustami, HM, al-Akhlāq (Jakarta: Penerbit Bulan Bintang, cet. II, 1962), 184.

55 Quraish Shihab, 'Tafsir Ahkam Khusyu' dalam Shalat, antara Syareat dan Hakekat', Jurnal Bimas Islam, 1/1 (2008): 25. 
Dan katakanlah: "Bekerjalah kamu, maka Allah akan melihat pekerjaanmu, begitu juga Rasul-Nya dan orang-orang mukmin, dan kamu akan dikembalikan kepada (Allah) yang mengetahui yang gaib dan yang nyata, lalu diberitakanNya kepada kamu apa yang telah kamu kerjakan."

(Surah al-Tawbah, 9:105)

Ringkasnya di sini, seorang Muslim yang profesional perlu memastikan setiap gerak kerja dan pekerjaan operasinya sentiasa mengikut ajaran Islam dari segi halal-haramnya, niat melakukannya, cara melaksanakannya dan output pekerjaan tersebut.

\section{Ihsan sebagai Darjat yang Tinggi}

Al-Ihsān merangkumi tiga komponen definisi yang saling berkaitan di antara satu sama lain. ${ }^{56}$ Pertama, ihsan membawa maksud perbuatan yang betul, tingkah laku yang baik, kebajikan, keikhlasan, baik hati, belas kasihan, bersimpati, mementingkan orang lain, berperikemanusiaan dan sebagainya. ${ }^{57}$ Kedua, ihsan membawa maksud melakukan sesuatu perkara dengan cara yang terbaik (proficiency). Ketiga, ihsan membawa maksud sentiasa merasai kewujudan dan kehadiran Allah SWT serta diri sentiasa diperhatikan oleh-Nya dalam apa jua keadaan dan tindakan. Ianya bertepatan dengan Hadith berkaitan pertanyaan Jibril kepada Rasulullah SAW tentang maksud ihsan:

$$
\text { ما الإحسا ن؟ قال: أن تعبد الله كأنك تراه فاءن لم تكن تراه فإنه يراك }
$$

"Apa itu Ihsan? Rasulullah menjawab: Ihsan itu ialah bahawa engkau menyembah Allah seolah-olah engkau melihat-Nya. Jika engkau tidak dapat melihat-Nya, maka sesungguhnya Dia melihat engkau." 58

\footnotetext{
56 Syed Othman al-Habshi, 'Management Ethics' dalam Islamic Management for Excellence - Revitalizing People for the Future, ed. Syed Othman al-Habshi et al. (Kuala Lumpur: Institut Perkembangan Minda, 1998), 72-73.

57 Maududi, S. Abul al-A 'la, Memahami al-Quran, jil. 2 (Delhi: al-Ikhlas, 1965), 562.

58 Al-Bukhārī, Șaḥ̄ḥ al-Bukhārī, Kitāb al-Īmān, Bāb Sū'āl Jibrīl al-Nabī, no. hadith 48 (Qāhirah: Dār al-Hadīth, t.t.); al-Nawawi, Saḥ̄h Muslim bi-Syarh al-Nawawī, Kitāb al-Īmān, Bāb Bayān al-Īmān wa al-Islām wa al-Iḥsān, no. hadith 93 (Beirūt: Dār al-Ma'rifah, 1994); al-Tirmidhī, Sunan al-Tìrmidh̄̄, Kitāb al-Īmān, Bāb Mā Jā’a fī Waṣf Jibra'il lil-Nabī SAW al-Īmān wa al-Islām, no. hadith 2619 (Beirūt: Dār al-Fikr, 1994).
} 
Ketiga-tiga definisi di atas memperlihatkan konsep ihsan yang luas dan sangat erat kaitannya dengan profesionalisme. Individu yang profesional akan sentiasa mengawasi diri daripada melakukan perbuatan yang dilarang oleh Allah SWT kerana timbul perasaan takut dan merasakan dirinya sentiasa diperhatikan oleh-Nya. Mereka sentiasa berwaspada dan lebih bertanggungjawab terhadap hukum syarak sepanjang melaksanakan tugas. Mereka juga sentiasa berusaha untuk memperbaiki dan meningkatkan kecemerlangan diri sehingga boleh mendatangkan manfaat dan kebajikan kepada semua pihak.

Sehubungan itu, interpretasi ihsan dalam pekerjaan tidak boleh lari daripada tiga perkara berikut;

\section{Ikhlāṣ al-Niyat (Niat yang ikhlas) ${ }^{59}$}

Ia merujuk kepada melakukan pekerjaan dengan motif yang bersih dan murni kerana Allah. Niat merupakan kunci utama dalam bekerja. Peri pentingnya niat ini terbukti apabila para ulama fiqh seperti Imam Nawawi meletakkan topik dan hadith tentang niat di awal pembahasan bukunya, Hadìth Arba 'ìn. Niat yang betul dan ikhlas cukup penting dalam profesionalisme. Niat yang betul dan ikhlas membantu meningkatkan profesionalisme dari segi kejelasan motif, arah tuju yang betul, matlamat yang nyata dan sebagainya. Sabda Rasulullah SAW:

$$
\begin{aligned}
& \text { إنما الأعهال بالنيات وإنها لكل امرى ما نوى فمن كانت هجرته إلى الله }
\end{aligned}
$$

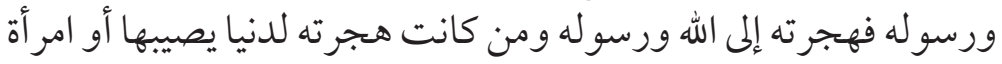

$$
\begin{aligned}
& \text { يتزوجها فهجرته إلى ما هاجر إليه ورجيه }
\end{aligned}
$$

"Sesungguhnya amalan-amalan itu bergantung pada niat, dan setiap orang akan mendapatkan sesuai yang diniatkannya. Maka sesiapa berniat hijrah kepada Allah dan Rasul-Nya, maka hijrahnya menuju Allah dan Rasul-Nya, dan sesiapa berniat hijrah untuk dunia yang akan diperolehnya atau wanita yang akan berkahwin dengannya, maka hijrahnya itu pun akan sampai pada apa yang diniatkannya." 60

\section{Itqān al-'Amal (Rapi dalam bekerja)}

\section{Firman Allah SWT:}

59 Fawzī Sanqarth, al-Taqarrub ilā Allah Ṭarīq al-Tawfìq (Beirūt: Dār al-Nahḍah alIslāmiyyah, cet., 1994), 17.

60 Abū Dāwūd, Sunan Abī Dāwūe, Kitāb al-Ṭalāq, Bāb fĩ Mā 'Uniya bihi al-Ṭalāq wa al-Niyāt, no. hadith 1882 (Beirūt: Dār al-Risālah al-'Alamiyyah, 2009). 


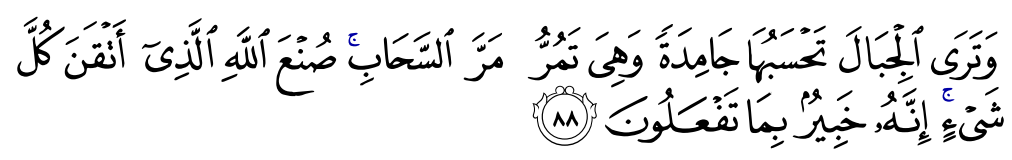

"Dan engkau melihat gunung-gunung, engkau menyangkanya tetap membeku, padahal ia bergerak cepat seperti bergeraknya awan; (Demikianlah) perbuatan Allah yang telah membuat tiap-tiap sesuatu dengan serapi-rapi dan sebaik-baiknya. Sesungguhnya ia amat mendalam pengetahuannya akan apa yang kamu lakukan."

(Surah al-Naml, 27:88)

Seorang yang profesional akan sentiasa bekerja dengan rapi. Ajaran Islam sentiasa memerintahkan untuk menyempurnakan amal, contohnya menyembelih haiwan dengan cepat dan dengan alat yang tajam, solat berjemaah harus rapi, wuduk dengan air yang suci dan mensucikan, serta tertib, puasa dengan menyempurnakan amal zahir dan batin. Kerapian kerja di sini merangkumi dari segi kemampuan menguruskan masa, menguruskan kewangan, mahupun menguruskan permasalahan lain.

\section{Jawdah al-Adā' (Melakukan dan menyelesaikan pekerjaan hingga akhir)}

Seorang yang profesional akan melaksanakan tugasnya sampai akhir meskipun berhadapan dengan masalah yang cukup besar. Tanggungjawab seorang yang profesional jauh lebih besar berbanding seorang yang biasa (amatur). Sehingga dalam penyelesaian pekerjaan, dikerjakan sampai selesai (tuntas) walaupun yang dikerjakan mungkin masalah yang cukup besar dalam kalangan manusia. Fenomena yang ada kadang-kadang ketika mengerjakan sesuatu, apabila berdepan dengan sedikit masalah sahaja tidak ingin menyelesaikan pekerjaan hingga akhir. Rasa cepat putus asa itu sangat jauh dari sikap seseorang yang profesional. Seorang profesional apabila berhadapan dengan suatu masalah, dia akan terus cuba menyelesaikan masalah tersebut dan akan tetap berusaha menyelesaikan tugas yang dibebankan kepadanya. Firman Allah SWT:

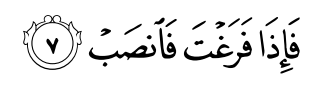

"Kemudian apabila engkau telah selesai (daripada sesuatu amal soleh), maka bersungguh-sungguhlah engkau berusaha (mengerjakan amal soleh yang lain)."

(Surah al-Insyirāḥ, 94:7) 
Secara keseluruhannya, ketiga-tiga dasar profesionalisme Islam di atas dapat dirumuskan dalam Rajah 2 berikut.

Rajah 2: Dasar Profesionalisme Islam.

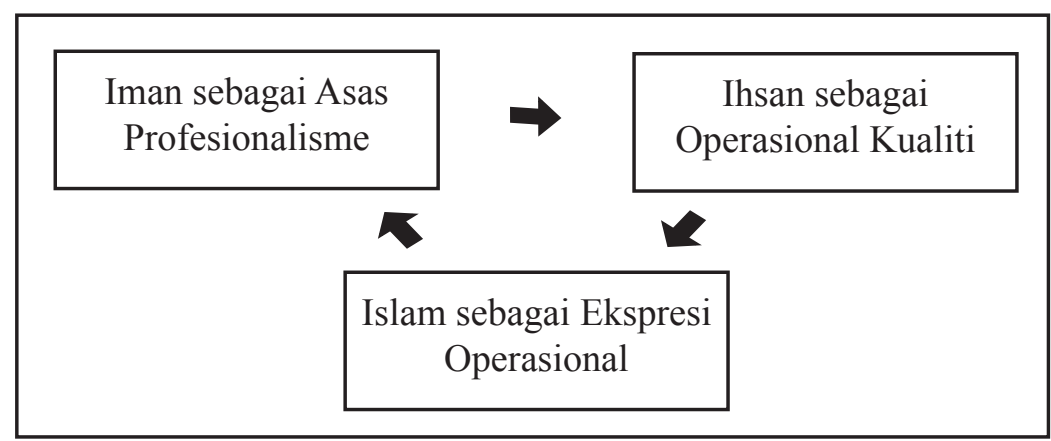

Sumber: Diubah suai daripadaYūsuf al-Qaraḍāwī. ${ }^{61}$

\section{Ciri-ciri Profesionalisme Islam}

Profesionalisme dalam Islam terkait kepada beberapa ciri berikut: ${ }^{62}$

\section{a. Kafa'ah (mampu)}

Kafa'ah merujuk kepada adanya keahlian dan kecekapan dalam bidang pekerjaan yang dilakukan. Kafa'ah diperolehi melalui pendidikan, latihan, serta pengalaman. Islam menetapkan bahawa seseorang yang dilantik untuk jawatan, jabatan, atau tugas-tugas tertentu, lebih-lebih lagi yang berkaitan dengan kepentingan orang ramai, haruslah orang yang mempunyai kemahiran dan kecekapan dalam tugas atau jawatan tersebut. Firman Allah SWT:

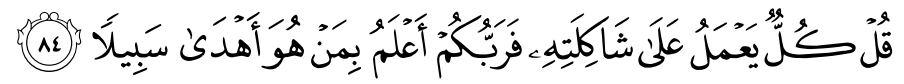

"Katakan tiap-tiap orang berbuat menurut keadaanya (keahliannya) masing-masing. Maka Tuhanmu lebih mngetahui siapa yang lebih benar (profesional) jalannya."

(Surah al-Isrā', 17:84)

\footnotetext{
61 Yūsuf al-Qaraḍāwī, Khașā'iṣ al- 'Āmmah li al-Islām (Qāhirah: Mu'assasah alRisālah, 1989).

62 Yūsuf al-Qaraḍāwī, Khașā' iṣ al- 'Ámmah li al-Islām, 45.
} 
Islam mengingatkan tindakan mengangkat orang yang bukan ahlinya atau orang yang tidak tepat dapat digolongkan orang yang melanggar amanat dan khianat terhadap Allah SWT, Rasul dan kaum Mukminin.

\section{b. Himmah al-'Amal (semangat kerja)}

Semangat kerja muncul kerana adanya motivasi kerja. Jika motivasinya berterusan, maka terhasillah semangat kerjanya tinggi. Islam mengajar kita unuk bekerja keras, serta bersungguh-sungguh mencurahkan tenaga dan komited dalam menjalankan pelbagai pekerjaan dengan menjadikan motivasi ibadah sebagai pendorong utama di samping motivasi ganjaran (al-thawāb), hukuman ( $a l$ - ‘q $\bar{a} b)$ dan kejayaan material.

Seseorang dikatakan mempunyai sikap profesional jika dia selalu bersemangat dan bersungguh-sungguh dalam menjalankan pelbagai pekerjaan yang menjadi tugasnya. Islam sangat menggalakkan setiap Muslim bekerja keras, bersungguh-sungguh mencurahkan tenaga, bijak mengurus masa ${ }^{63}$ dan komited dalam menjalankan pelbagai pekerjaan yang menjadi tugas dan tanggungjawabnya.

Dorongan utama yang diberikan kepada seorang Muslim semasa dia bekerja adalah bahawa Islam memandang semua aktiviti pekerjaan terikat dengan Syariah Islam sebagai bentuk peribadatan kepada Allah SWT. Hal ini selari dengan makna ihsan sebagaimana yang telah dijelaskan sebelum ini.

Oleh kerana itu, Allah SWT dan Rasulullah SAW sangat menyukai setiap Muslim yang rajin, bekerja keras dan mempunyai etika kerja yang tinggi. Seorang Muslim dianjurkan untuk tetap berbuat sesuatu di saat tiada pekerjaan walaupun hanya untuk membantu saudaranya yang lain. Sabda Rasulullah SAW:

$$
\text { إن الله تعالى يحب إذا عمل أحدكم عملا أن يتقنه }
$$

"Sesungguhnya Allah mencintai seseorang yang apabila ia mengerjakan sesuatu kerja, ia laksanakan dengan tekun." 64

c. 'Awfu bi al- 'Uqūd (berpegang pada janji)

Pekerjaan sentiasa melibatkan interaksi dengan orang lain, baik sebagai rakan sejawat mahupun pelanggan. Dalam realiti perniagaan wujud pelbagai

63 Yūsuf al-Qaraḍāwī, al-Waqt fì Hayāh al-Muslim (Qāhirah: Maktabah Wahbah, 1996), 22-25.

64 Al-Munāwī, Fayḍ al-Qadīr Sharh al-Jāmi “ al-Ṣaghīr, no. hadith 1861 (Beirūt: Dār al-Fikr 1972). 
komitmen untuk mendapat faedah. Salah satu usaha memelihara komitmen itu adalah dengan membuat kontrak perniagaan, perjanjian pekerjaan ataupun perjanjian.

Seorang Muslim dituntut untuk berpegang pada janji dan memenuhi pelbagai tuntutan apa yang telah dikontrakkan, bukan semata-mata sebagai faktor tindakan profesional yang menguntungkan. Allah SWT berfirman:

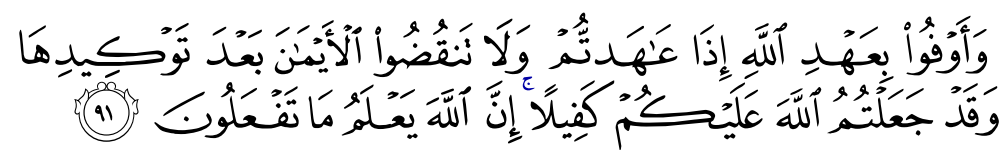

"Dan sempurnakanlah pesanan-pesanan dan perintah-perintah Allah apabila kamu berjanji; dan janganlah kamu merombak (mencabuli) sumpah kamu sesudah kamu menguatkannya (dengan nama Allah), sedang kamu telah menjadikan Allah sebagai Penjamin kebaikan kamu; Sesungguhnya Allah sedia mengetahui akan apa yang kamu lakukan."

(Surah al-Naḥl, 16:91)

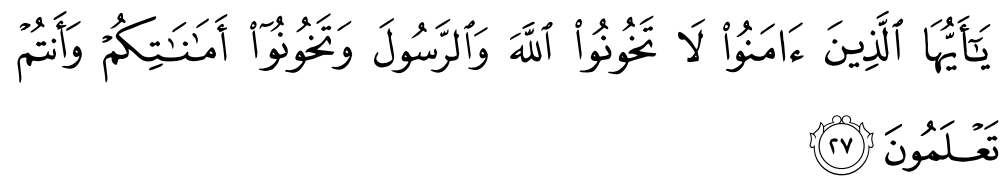

"Wahai orang-orang yang beriman! janganlah kamu kamu mengkhianati amanah-amanah kamu, sedang kamu mengetahui (salahnya)."

(Surah al-Anfāl, 8:27)

Dalam banyak hal, berpegang dan memenuhi perjanjian ini membawa manfaat kepada memperluaskan jaringan usaha dan persahabatan. Oleh kerana itu, perilaku memenuhi janji dipandang juga sebagai pelaburan kebajikan dan cerminan kepada keperibadian Islam (al-syakhșiyyah al-Islāmiyyah). Tindakan ini adalah tindakan profesional Muslim ( $\bar{u} l \bar{u} a l-b \bar{a} b)$ yang berwawasan.

\section{d. Anșār Allah (Penolong)}

Tindakan profesional bagi seorang Muslim tercermin daripada keperibadian Islam (al-syakhșiyyah al-Islämiyyah) yang secara zahir (kenyataan) melahirkan 'amal șālih. Ia merupakan suatu bentuk kesinambungan keimanan yang dirasakan oleh manusia di mana ia hidup. Seakan-akan ia menjadi rahmat Allah kepada manusia melalui ilmu yang dimilikinya untuk membantu sesama 
manusia. Dengan ilmu itulah sikap profesional lahir dan dipraktik untuk kemaslahatan manusia. Firman Allah:

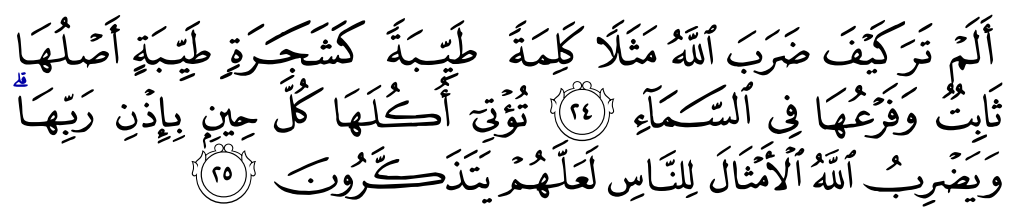

"Tidakkah kamu memperhatikan bagaimana Allah telah membuat perumpamaan kalimat yang baik seperti pohon yang baik, akarnya kuat dan cabangnya (menjulang) ke langit, (pohon) itu menghasilkan buahnya pada setiap waktu dengan seizin Tuhannya. Dan Allah membuat perumpamaan itu untuk manusia agar mereka selalu ingat."

(Surah Ibrāhīm, 14: 24-25)

Ia ibarat pohon yang berakarkan iman disertai dengan ilmu yang kukuh kuat menghunjam ke bumi, cabang dan rantingnya menjulang ke langit dan membuahkan amal yang dapat dinikmati oleh sesiapa yang memerlukan. ${ }^{65}$ Menolong manusia seumpama dengan menolong agama Allah. Semakin sering seseorang itu menjadi penolong bagi sesama manusia dengan cara yang baik dan benar, nescaya semakin mengubahkan kedudukannya di tengah-tengah masyarakat.

e. Amanah

Seseorang diberi gelaran al-amīn, bermakna orang merasa selamat apabila menyerahkan pekerjaan atau amanah kepadanya kerana ia bertanggungjawab atas pekerjaan yang diamanahkan pada dirinya. Firman Allah SWT:

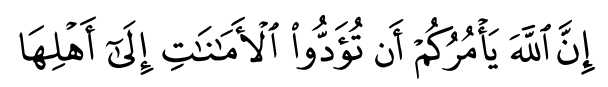

"Sesungguhnya Allah menyuruh kamu menyampaikan amanat kepada yang berhak menerimanya...."

(Surah al-Nisā', 4:58)

Dengan sikap amanah, orang akan merasa aman dari pengkhianatan, kecurangan, dusta, dan ingkar janji. ${ }^{66}$ Rasulullah SAW menggambarkan orangorang yang selalu melanggar amanah sebagai orang munafik.

\footnotetext{
65 Sayyid Qutub, F̄̄ Zilāl al-Qur'ān, vol. 5, 85.

66 Ibn Manẓūr, Abū al-Faḍl Jamāl al-Dīn Muḥammad b. Mukarram, Lisān al- 'Arab vol. 13 (Beirūt: Dār Șādir, 1990), 24; Lihat Yūsuf al-Qaraḍāwī, Dawr al-Qiyām wa al-Akhlāq fi al-Iqtișād al-Islāmī (Qāhirah: Maktabah Wahbah, 1995), 54.
} 


$$
\text { آية المنافت ثلاث إذا حدث كذب وإذا وعد أخلف و إذا اؤتمن خان }
$$

"Tanda-tanda munafiq ada tiga; Jika bercakap dusta, jika berjanji mengingkari dan jika diberi amanah khianat. " 67

Sikap amanah ditunjukkan oleh peribadi Rasulullah SAW ketika baginda dipercayai sebagai pengurus perniagaan oleh Sayidatina Khadijah. ${ }^{68}$ Kejujuran yang disertai dengan kecerdikan melahirkan berkat atas usaha yang dijalankannya.

Berdasarkan huraian tentang ciri-ciri profesionalisme Islam di atas, ianya boleh diringkaskan sebagaimana dalam Rajah 3 berikut.

Rajah 3: Ciri-ciri Profesionalisme Islam.

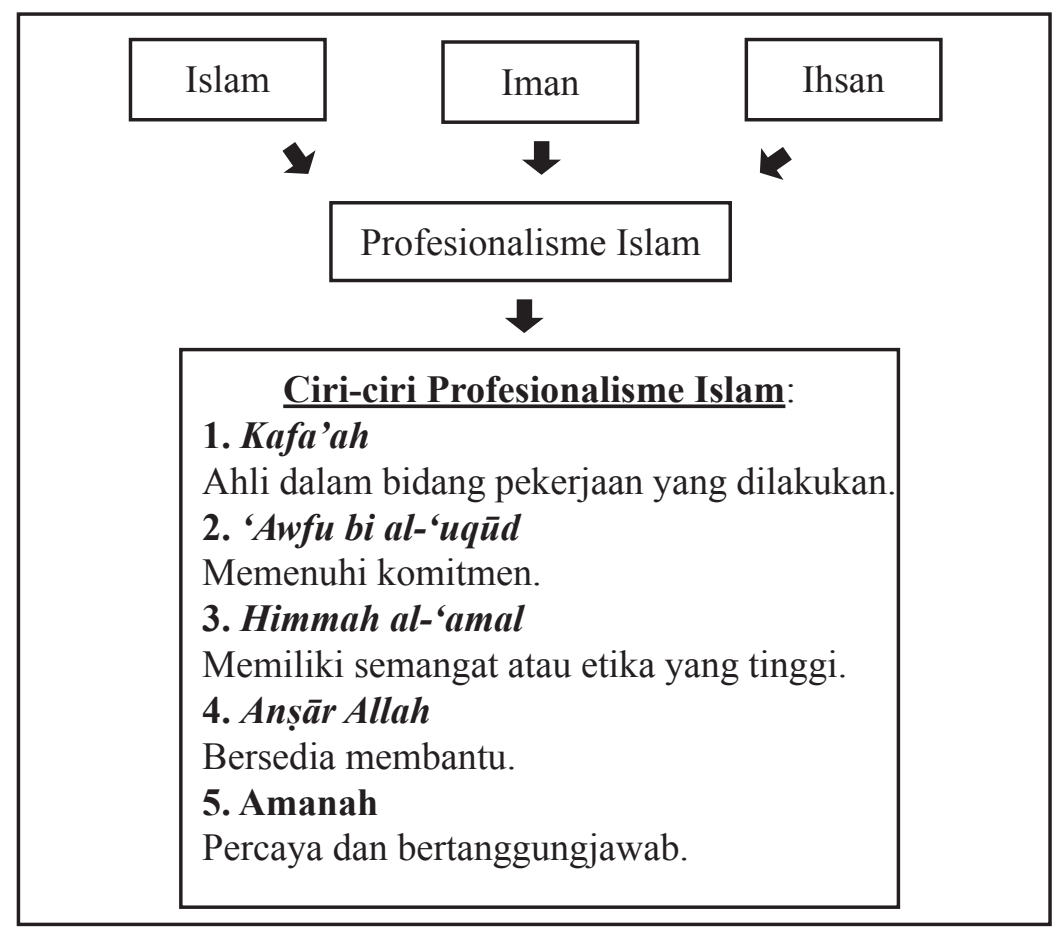

Sumber: Diubah suai daripada Yūsuf al-Qaraḍāwī. ${ }^{69}$

67 Al-Tirmidhī, Sunan al-Tirmidhī, Kitāb al-Īmān 'an Rasūl Allāh SAW, Bāb Mā Jā’a fì 'Alāmah al-Munāfiq, no. hadith 2555 (Beirūt: Dār al-Fikr, 1994).

68 Afzalurrahman, Muhammad sebagai Seorang Peniaga (Jakarta: Penerbit Yayasan Swarna Bhumy, cet. 3, 1997), 5; Didin Hafudhuddin, Hendri Tanjung, Manajemen Syariah dalam Aplikasi (Jakarta: Penerbit Gema Insani Press, cet. 2, 2003), 52.

69 Yūsuf al-Qaraḍāwī, Khașā' is al- 'Āmmah li al-Islām. 


\section{HUBUNG KAIT ANTARA KEPERIBADIAN ISLAM DAN PROFESIONALISME DALAM PEKERJAAN}

Dalam konteks pekerjaan, hubung kait antara keperibadian Islam dan profesionalisme adalah seperti paparan dalam Rajah 4 yang merupakan gabungan antara Rajah 1 dan 3 terdahulu.

Sebagaimana dimaklumi, keperibadian Islam hanya akan terhasil kombinasi daripada pola fikir dan pola sikap Islam. Di sini, individu yang berkeperibadian Islam memperolehi maklumat mengenai Islam, memahami dan membuat keputusan tentang sesuatu perkara dan perbuatan sesuai dengan hukum syarak, sehingga dia mampu menggali undang-undang, mengetahui halal dan haram, mempunyai kesedaran dan pemikiran yang matang, mampu menyatakan hujah yang kuat dan tepat, serta mampu menganalisis pelbagai perbuatan dengan betul bersesuaian dengan parameter syarak. Sehingga dengan itu, individu berkenaan dapat menghasilkan perbuatan dan tingkah laku bagi memenuhi tuntutan naluri dan keperluan jasmaninya dengan berlandaskan kepada ajaran Islam. Perbuatan dan tingkah laku yang berdasarkan keimanan dan kefahaman yang betul ini membawa kepada suatu cara kerja yang menekankan profesionalisme.

Rajah 4: Hubung kait antara Keperibadian Islam dan Profesionalisme.

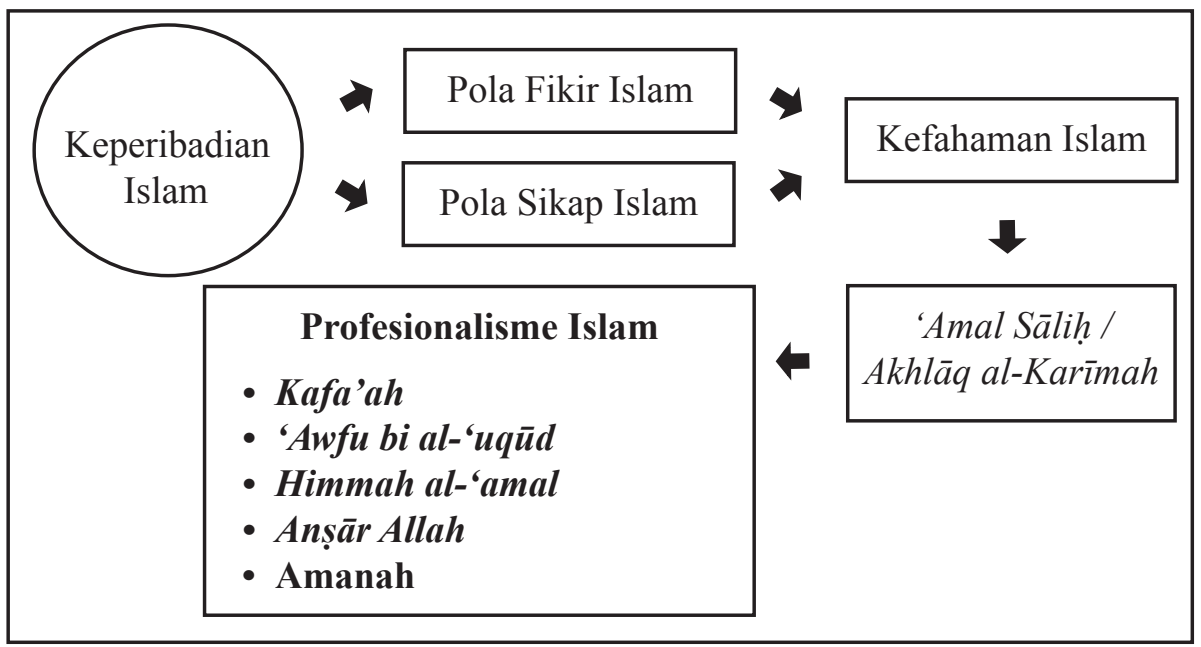

Sumber: Diubah suai daripada Mohammad Ghozali. ${ }^{70}$

70 Mohammad Ghozali, 'al-Tamakkan al- 'Amal fī Naẓariyyah al-Islām,' (International Conference on Sustainable Innovation (ICOSI), Universitas Muhammadiyah Yogyakarta, Indonesia, 2012). 
Dengan kata lain, profesionalisme merupakan natijah daripada keperibadian Islam yang secara zahir membuahkan 'amal șäliḥ dan akhlāq al-karīmah. Prinsip keimanan yang mendasari profesionalisme Islam berupaya membina konsep, pandangan, sikap, gaya berfikir sehinggalah penentuan bentuk tindakan individu dalam organisasi. ${ }^{71}$ Individu yang beriman berupaya melaksanakan profesionalisme dalam pekerjaan di mana segala bentuk amanah yang dipertanggungjawabkan kepadanya ditunaikan dengan ikhlas untuk mendapatkan keredhaan Allah dan terus berazam untuk melakukan yang terbaik lantaran menyedari pengawasan Allah adalah lebih tajam daripada pengawasan manusia. Di sinilah dasar iman, Islam, dan ihsan diaplikasikan dalam kerja yang profesional. Syariah Islam dipegang teguh dalam segala persoalan mahdah mahupun ghayr mahdah sehingga menghasilkan kualiti kerja yang sehabis baik.

Untuk itu, individu yang memiliki profesionalisme mestilah memiliki ciri kafa'ah (mampu), himmah al-'amal (semangat kerja), 'awfu bi al'uqūd (memegang perjanjian), anșār Allah (penolong) dan amanah. Hanya mereka yang memiliki keperibadian Islam sahaja dapat menghayati ciri-ciri profesionalisme tersebut. Mereka akan sentiasa berusaha untuk meningkatkan kemahiran dan kecekapan pekerjaan, sentiasa bermotivasi, komited, sedia membantu dan bertanggungjawab atas pekerjaan yang diamanahkan pada dirinya.

\section{IMPLIKASI KEPERIBADIAN ISLAM DAN PROFESIONALISME DALAM PEKERJAAN}

Menyedari keperibadian Islam dan profesionalisme mempunyai hubung kait yang amat erat, maka kombinasi kedua-duanya pasti dapat memberi kesan yang positif terhadap kualiti pekerjaan dan kecemerlangan organisasi. Secara lebih terperinci, implikasi keperibadian Islam dan profesionalisme dalam konteks pekerjaan adalah seperti berikut.

\section{Melahirkan pekerja yang beretika}

Keperibadian Islam yang dimiliki oleh pekerja Muslim menjadi momentum kepada mereka untuk bekerja secara profesional dan dalam masa yang sama menjadipenghalangkepada amalan kerjatidak beretika. Kebertanggungjawaban pekerja Muslim terhadap pekerjaan adalah atas kesedaran bahawa pekerjaan dan

71 'Abd al-Raḥman bin Nāṣir al-Sa'īdī, al-Tawdị̄h wa al-Bayān li Shajarat al-İmān (Maktabah Adhuwa al-Salaf, cet. 1, 1998), 139. 
tugas itu merupakan amanah daripada Allah SWT. Mereka bertanggungjawab untuk melaksanakan tugas dengan ikhlas, telus, cekap, dan tidak mencampuradukkan antara urusan kerja dan peribadi. Dalam masa yang sama, mereka sentiasa berwaspada dan lebih bertanggungjawab terhadap hukum syarak sepanjang melaksanakan tugas kerana merasakan diri sentiasa diawasi dan diperhatikan oleh-Nya. Mereka juga sentiasa berusaha bersungguh-sungguh untuk memperbaiki dan meningkatkan kecemerlangan diri.

\section{Menghasilkan kerja berkualiti}

Profesionalisme Islam meletakkan konsep iman, ilmu dan ihsan sebagai dasar utama. Kesepaduan ketiga-tiga dasar ini menjadi piawaian kepada semua bentuk tindakan dan perlakuan pekerja Muslim. Oleh itu, apa jua perlakuan atau tindakan yang dilaksanakan atas nama profesionalisme, akan dipastikan bertepatan dengan syariat Islam dan memenuhi kualiti kerja yang terbaik. Keprofesionalan seseorang terhasil daripada paduan ilmu, kemahiran dan kepakaran yang dimiliki. Ini diperkukuhkan lagi dengan keperibadian dan sahsiah diri yang bertanggungjawab (accountable) terhadap tugas yang dilaksanakan. Segala tindakan yang diambil sentiasa dipastikan mendatangkan manfaat kepada semua pihak.

\section{Membantu pencapaian matlamat organisasi}

Komitmen yang tinggi terhadap pekerjaan dapat menyumbang kepada peningkatan produktiviti dalam organisasi dan seterusnya dapat merealisasikan pencapaian matlamat organisasi secara keseluruhannya. Profesionalisme dan keperibadian Islam yang menekankan konsep tauhid kepada Allah SWT dapat mewujudkan tahap keimanan yang tinggi dalam diri para pekerja Muslim yang profesional. Keimanan kepada Allah ini menjadi keutamaan dalam diri mereka yang menetapkan matlamat mereka bekerja bukan sekadar untuk mendapat ganjaran kewangan dan memenuhi matlamat organisasi, bahkan lebih daripada itu ia bermatlamat untuk mencapai kejayaan di dunia dan juga akhirat.

\section{Mewujudkan organisasi yang cemerlang}

Pencapaian matlamat organisasi secara zahirnya turut menunjukkan kecemerlangan sesebuah organisasi. Ia merupakan implikasi yang positif hasil daripada pengamalan keperibadian Islam dan juga profesionalisme dalam pekerjaan. Pendekatan yang dibawa oleh profesionalisme dalam Islam, kecemerlangan tidak sekadar diukur berdasarkan pencapaian matlamat 
organisasi sahaja. Kecemerlangan yang sebenar adalah apabila seseorang itu dapat menyumbang manfaat kepada kecemerlangan pembangunan ummah sehingga mampu merealisasikan matlamat penciptaan manusia itu sendiri iaitu mencapai redha Allah SWT. Kecemerlangan sebegini hanya dapat diperoleh oleh mereka yang berupaya mengasimilasikan antara profesionalisme dengan keperibadian Islam dalam konteks pekerjaan dan segenap lapangan kehidupan mereka.

\section{KESIMPULAN}

Secara teorinya, tidak dinafikan bahawa keperibadian Islam cukup signifikan dalam usaha mewujudkan profesionalisme dalam pekerjaan. Malah kombinasi kedua-duanya membawa kepada implikasi positif kepada kecemerlangan organisasi dan ummah sejagat. Justeru, pihak berkaitan perlu mengambil langkah sewajarnya bagi memupuk keperibadian Islam dan membina tahap profesionalisme yang tinggi dalam kalangan para pekerja Muslim bagi menangani isu ketidakcekapan dan salah laku moral yang semakin menular dalam masyarakat masa kini. Lahirnya golongan profesional Muslim yang berwibawa ini membolehkan mereka tampil sebagai contoh teladan (qudwah) yang sebenar kepada segenap lapisan masyarakat.

\section{RUJUKAN}

'Abd al-Hamid Mursi, al-Syakhșiyah al-Muntajah (Mesir: Maktabah Waḥbah, 1985).

'Abd al-Rahmān al-Mālik, al-Siyāsah al-Iqtiṣādiyah al-Muthlā (Bangil Jatim: al-Izzah, cet. 1, 2001).

'Abd al-Raḥman bin Nāṣir al-Sa'īdī, al-Tawụ̂̄h wa al-Bayān li Shajarat alImān (Maktabah Adhuwa al-Salaf, cet. 1, 1998).

'Umar Sulayman al-Asqar, Ciri-ciri Keperibadian Muslim, terj. (Jakarta: Penerbit Raja Grafindo Persada, cet. 2, 1996).

'Umar Sulayman al-Asqar, Maqāșid al-Mukallifin, al-Niyah fì al-'Ibādāt, (Jordan: Dār al-Nafā'is li al-Nasyr wa al-Tawzī', cet. v, 1999).

Abū Dāwūd, Sulayman Ibn al-Ash'ath al-Sijistānī, Sunan Abī Dāwūd (Beirūt: Dār al-Risālah al-'Alamiyah, 2009).

Adler, A., The Neurotic Constitution: Outline of a Comparative Individualistic Psychology and Psychotherapy (New York: John Wiley \& Sons, 1985).

Afzalurrahman, Muhammad sebagai Seorang Peniaga (Jakarta: Penerbit Yayasan Swarna Bhumy, cet. 3, 1997). 
Ahmad Warson Munawwir, al-Munawwir (Surabaya: Penerbit Pustaka Progresif, 1997).

Alī Sami al-Nasyar, Manāhij al-Baḥth 'inda Mufakkīr al-Islāmiyyah (Dār alMa‘ārif, 1978).

Al-Bukhārī, Abū 'Abd Allāh Muḥammad b. Ismā'īl b. Ibrāhīm al-Mughīrah. Șaḥ̄ḥ al-Bukhārī, vol. 3 (Qāhirah: Dār al-Hadīth, t.t.).

Burger, Jerry M., Personality Theory and Research (USA California: Wadsworth Publishing Company, Belmont, 1986).

Bustami, HM, al-Akhlāq (Jakarta: Penerbit Bulan Bintang, cet. II, 1962).

Didin Hafudhuddin, Hendri Tanjung, Manajemen Syariah dalam Aplikasi (Jakarta: Penerbit Gema Insani Press, cet. 2, 2003).

Fawzī Sanqarth, al-Taqarrub ilā Allah Ṭarīq al-Tawfìq (Beirūt: Dār al-Nahḍah al- Islāmiyyah, 1994).

Al-Ghazālī, Abū Hamid Muḥammad bin Muhammad, al-Tibr al-Masbūk fi Nașihāh al-Muluk (Qāhirah: Syirkah al-Ṭaba'ah alā Fanniyah alMutahidah, 1967).

Al-Ghazālī, Abū Hāāmid Muḥammad bin Muhammad, Ihyyā'Ulūm al-Dīn, vol. 3 (Damsyik: Dār al-Khayr, 1990).

Al-Ghazālī, Abū Hāmid Muḥammad bin Muḥammad. Ma'ārij al-Quds fì Madārij Ma 'rifāt al-Nafs (Qāhirah: Maktabah al-Jundi, 1968).

Gibson \& Donnelly, Organizations, 8th ed. (Richard D. Irwin, Inc, 1995).

Hafidz Abdurrahman, Islam, Politik dan Spiritual (Singapore: Lisan al-Haq, 1998).

Hall, C.S. \& Lindzey, G., Introduction to Theories of Personality (Canada: John Wiley \& Co., 1985).

Hasan al-Banna, Majmū'ah al-Rasā'il li al-Imām al-Syāhid Hasan al-Banna (Mesir: al-Bașā'ir wa al-Dirāsat, t.t.).

Hasan al-Banna, Risalah Pergerakan Ikhwan al-Muslimin, terj. (Solo: Penerbit Era Intermedia, 2000).

Ibn Manẓūr, Abū al-Faḍl Jamāl al-Dīn Muhammad b. Mukarram, Lisān al'Arab, vol. 15 (Beirūt: Dār Șādir, 1990).

John M, Ivancevich, Human Resource Management; Foundations of Personnel (Homewood, III: Richard D. Irwin, 1992).

Maddi, Salvatore R., Personality Theories: A Comparative Analysis (California USA: Books/Cole Publishing Company, Pasific Grove. 1994).

Maududi, S. Abul al-A 'la. Memahami al-Quran, jilid 2 (Delhi: al-Ikhlas, 1965). 
Mohammad Ghozali, 'al-Tamakkan al-'Amal fĩ Naẓariyyah al-Islām,' (International Conference on Sustainable Innovation (ICOSI), Universitas Muhammadiyah Yogyakarta, Indonesia, 2012).

Mohd. Affandi Hassan, The Tawhidic Approach in Management and Public Administration (Kuala Lumpur: INTAN, 1992).

Muḥammad Ḥusayn 'Abd Allāh, Mafāhim al-Islāmiyyah, al-Rūh, al-Idrāk, al'Amāl, al-Syakhșiyyah (Beirūt: Dār al-Bayāriq, cet. 1, 1996).

Muḥammad Hụsayn 'Abd Allāh, Min Muqawwimāt al-Nafsiyah al-Islāmiyyah (Dār al-Bayāriq, 2004).

Muhammad Ismail Y.M. Karebet W., Menggagas Bisnis Islami (Jakarta: Penerbit Gema Insani Press, 2002).

Muhammad Ismail Y.M. Karebet W., Manajemen Strategis Presfektif Islam (Jakarta: Penerbit Khayr al-Bayan, 2003).

Muhammad Muhammad Ismā'īl, al-Fikr al-Islāmī (Beirut: Maktabah alWa'iy, 1985).

Al-Munāwī, 'Abd al-Ra'ūf b. Tāj al-'Ārifīn, Fayḍ al-Qad̄̄r Sharh al-Jāmi ‘ al-Ṣaghīr (Beirut: Dār al-Fikr, 1972).

Muslim, Ibn al-Hajjaj al-Qushayri, Șaḥ̄h Muslim (Mesir: 'Īsā al-Bābī alHalabī, 1970).

Al-Nawawī, Muḥy al-Dīn Abū Zakariyyā Yahyā̄ b. Syaraf, Saḥ̄ḥ Muslim biSyarh al-Nawawī, vol. 18 (Beirūt: Dār al-Ma rifah, 1994).

Nor 'Azzah Kamri, 'Etika Pengurusan Islam dan Konvensional: Satu Analisis Perbandingan', Jurnal Syariah 10/2 (2002): 43-66.

Quraish Shihab, 'Tafsir Ahkam Khusyu' dalam Shalat, antara Syareat dan Hakekat', Jurnal Bimas Islam 1/1 (2008).

Ryckman, M.R, Theories of Personality (USA: Wadswort/Thomson Learning Co., 2000).

Al-Suyūṭ̂̄, 'Abd al-Raḥman. al-Jāmi ' al-Ṣaghīr fì Ahạdīth al-Bashīr wa alNadhīr (Beirūt: Dār al-Fikr, 1980).

Sayyid Quțub, F̄̄ Zilāl al-Qur'ān, vol. 10 (Beirūt: Dār al-Syuruq, 1412 H).

Schultz, D. \& Schultz, S.E., Theories of Personality (USA: Wadsworth, Thomson Learning, 2001).

Shahabuddin Hashim \& Rohizani Yaakup, Teori Personaliti Perspektif Islam, Timur dan Barat (P. Pinang: Rhythm Industries Sdn. Bhd, 2004).

Syed Othman al-Habshi, 'Management Ethics' dalam Islamic Management for Excellence - Revitalizing People for the Future, ed. Syed Othman alHabshi et al. (Kuala Lumpur: Institut Perkembangan Minda, 1998). 
Taq̄i al-Dīn al-Nabhānī, al-Syakhșiyyah al-Islāmiyyah, vol. I (Beirūt: Dār alUmmah, 1994).

Taq̄i al-Dīn al-Nabhānī, al-Syakhșiyyah al-Islāmiyyah (Beirūt: Dār al-Ummah, cet. vi, 2003).

Al-Tirmidhī, Abū 'Īsā Muḥammad b. 'Īsā b. Sawrah b. Mūsā, Sunan alTirmidhī, vol. 5 (Beirūt: Dār al-Fikr, 1994).

Yadi Purwanto, Etika Profesi Psikologi Profetik Perspektif Psikologi Islam (Bandung: Penerbit PT Refika Aditama, 2007).

Yong Gan Chok, 'Persepsi Pelajar Tingkatan Dua dan Empat terhadap CiriCiri Personaliti dan Kemahiran Guru Bimbingan dan Kaunseling di Dua Buah Sekolah Daerah Petaling' (Disertasi Sarjana, Universiti Malaya, 2003).

Yūsuf al-Qaraḍāwī, al-'Aql wa al-'Ilm fì al-Qur'ān al-Karīm (Beirūt: Mu'assasat al-Risālah, 2001).

Yūsuf al-Qaraḍāwī, al-Waqt fì Hayāh al-Muslim (Qāhirah: Maktabah Wahbah, 1996).

Yūsuf al-Qaraḍāwī, Dawr al-Qiyām wa al-Akhlāq fì al-Iqtiṣād al-Islāmī (Qāhirah: Maktabah Wahbah, 1995).

Yūsuf al-Qaraḍāwī, Khașā'iṣ al- 'Āmmah li al-Islām (Qāhirah: Mu'assasah alRisālah,1989).

Yusuf Qardhawi, Ciri-ciri Islam: Kajian Analitik (Surabaya: Penerbit Risalah Gusti, 1994). 